\title{
COMMERCIALIZATION OF THE MEDIA - TVP CASE
}

\author{
by Aleksandra Seklecka
}

In the process of political, economic and social changes that have taken place in Poland since 1989, state radio and television, so far carefully controlled by the communist government, could not remain unaffected. The establishment of a new order required several years and involved numerous changes in management and the content of programs. It is often said that this process has not been completed yet. What can be observed after twenty years of transformation is the commercialization of media, whose "public" status is present only in their name. This is particularly apparent in the analysis of Polish television. In fact, the activity of this media is based on certain market mechanisms, including the desire to reach high viewership, attract the attention of advertisers and as a consequence, to maximize profit.

Public media in Poland include Polish Television (i.al. TVP 1, TVP 2, TVP Info) and Polish Radio (PR 1, PR 2, PR 3, PR 4). The act on television and radio broadcasting of December 29, 1992 divided the state organizational entity into two single-handed joint-stock public purse companies. Their activity is supervised by collective organizations (boards and supervisory councils) acting on the basis of the act and appointed by the highest state organs in such a manner that, at least theoretically, no political 
power is able to take full control of the media. The media ought to be independent and the boundary of their independence should be shaped by the basic legal regulations and program tasks on the one hand, and the means limiting the range of the broadcasting activity on the other ${ }^{1}$. In fact, a commercial law company allows its owner, here The Treasury, or Secretary of the Treasury to be more specific, to control the financial situation of public media. Often such actions have a political dimension and are motivated by the political interest of particular governments.

As regards the content of programs, it is the realization of the public mission that constitutes the main task of public mass media. According to Jerzy Jastrzębski², the mission consists in "informing, educating and amusing, and entertainment is far less important". However, this idea has been lost, especially as far as TVP is concerned, which took place as a result of the commercialization and politicization of the media. This is even more visible, as no regulations, which would force the media to report on their program activity, were created. The control of the National Broadcasting Council is limited to checking reports on the activity of public media. Nonetheless, what is and what is not considered as a mission depends on the media themselves and their interpretation might be broad.

As for Polish public media, in particular television, advertisements constitute an important source of income. For this reason, they can be treated as a market product which, similarly to commercial media, needs to fight for viewers and advertisers. In the case of television, the license fee constitutes $17.2 \%$ of the total income, while the remaining sum comes from advertisements ${ }^{3}$. When the structure of programs in public television (TVP1, TVP2) is compared to those in commercial stations (Polsat, TVN) (see Table 1), it is visible that the rate of advertisement and telemarketing is only slightly lower in case of the former. The rate of films and theatre,

1 M. Mrozowski, Media masowe, Warszawa 2001, p. 48.

2 J. Jastrzębski, Misja, „czwarta władza” czy biznes? O potrójnej naturze mediów, [in:] Media a demokracja, eds. L. Pokrzycka, W. Mich, Lublin 2007, p. 23.

3 Sprawozdanie zarzadu z wykorzystania przez TVP S.A. wpływów z opłat abonamentowych na realizacje misji publicznej w 2009 roku, Warszawa 2010, p. 6. 
on the other hand, is the highest on both public stations ${ }^{4}$. What is also observed is a small number of shows aiming at entertaining the audience in TVP1. Still, as regards TVP2, their number is greater than in the case of Polsat. The number of political programs is similar in TVP and TVN. Public television outstrips the commercial media in the number of news bulletins, but here the difference is not considerable. This results in the statement, that what is public in public media is only the name, since their program structure is similar to that of commercial media.

Table 1. The percentage distribution of programs is weekly broadcastings of television stations between November 8, 2010 and November 14, 2010

\begin{tabular}{|l|r|c|c|c|}
\hline & \multicolumn{1}{c|}{ TVP1 } & \multicolumn{1}{c|}{ TVP2 } & \multicolumn{1}{c|}{ Polsat } & \multicolumn{1}{c|}{ TVN } \\
\hline Advertisement and telemarketing & $17.60 \%$ & $16.43 \%$ & $20.80 \%$ & $24.56 \%$ \\
\hline Theatre and film & $55.58 \%$ & $48.95 \%$ & $44.95 \%$ & $30.19 \%$ \\
\hline Entertainment & $5.36 \%$ & $15.76 \%$ & $12.35 \%$ & $29.44 \%$ \\
\hline Music & $0.40 \%$ & $0.24 \%$ & $2.48 \%$ & $\times$ \\
\hline Sports & $0.69 \%$ & $0.62 \%$ & $9.25 \%$ & $0.18 \%$ \\
\hline Political - economic - social programs & $4.91 \%$ & $3.37 \%$ & $1.45 \%$ & $4.31 \%$ \\
\hline News bulletins & $9.87 \%$ & $5.00 \%$ & $4.82 \%$ & $3.24 \%$ \\
\hline Artistic and cultural programs & $0.31 \%$ & $5.08 \%$ & $0.22 \%$ & $1.18 \%$ \\
\hline Educational and scientific programs & $0.67 \%$ & $1.23 \%$ & $0.22 \%$ & $1.94 \%$ \\
\hline Religious programs & $1.59 \%$ & $0.51 \%$ & $\times$ & $\times$ \\
\hline Others & $3.02 \%$ & $2.80 \%$ & $3.47 \%$ & $4.95 \%$ \\
\hline TOTAL BROADCAST HH:MM & $166: 45$ & $164: 22$ & $167: 39$ & $167: 56$ \\
\hline
\end{tabular}

Source: [Nielsen Audience Measurement 2010].

The commercialization of media is particularly visible if compared to the structure of programs in public television between 1995 and 2005, when there was an increase in the participation of feature films and adver-

\footnotetext{
4 Assigning film and theatre to the same category should be considered as a mistake, as the latter is in fact a missionary genre. What is more, it does not play an important role in the broadcast programming of particular stations.
} 
tisements and a decrease in mission programs ${ }^{5}$. However, it ought to be remembered that the realization of the mission in the situation when the income from the license fee is very limited is not an easy task. This results from a low exaction of this payment. What is more, numerous persons are excused from paying the fee, as in the case of elderly people over the age of seventy five or the disabled. What is worth mentioning, mission programs are not typically as popular, which is reflected in a low income from advertisement.

Commercialization results in the decrease in the quality of programs. Journalistic programs are in fact talk shows. Politicians, instead of presenting their work, become celebrities. Such a situation is the consequence of what Jan Kreft pointed out ${ }^{6}$, namely that celebrities attract attention, and as a result exert influence on the imagination of the masses. Public television, in particular TVP2, influenced by its manager Nina Terentiew, eagerly broadcasts entertaining programs, including shows, quizzes and talk shows. Terentiew's idea of what entertainment is aroused controversies and was accused of being kitschy.

Such a tendency is referred to as tabloidization. According to Stanisław Filipowicz, in the public media this phenomenon is illustrated by such programs as „Special Mission”, presenting the results of journalists' investigations of business and political matters, or the talk show "Ring"7. The tendency to copy commercial stations is visible in the program "Stars Dancing on Ice", which by Wojciech Pawlak, the then director of TVP2, was described as missionary, since it "teaches to dance" ${ }^{\text {. }}$. Still, if programs of this type are regarded as missionary, the viewers may get confused, as they do not see any differences between such programs and similar ones broadcast on commercial stations. Therefore, the existence of public media

\footnotetext{
5 Radio i telewizja w Polsce: Raport o stanie rynku. Materiał źródłowy do dokumentu: „Raport otwarcia: rynek radiowo-telewizyjny w Polsce”, Warszawa 2006, p. 44.

6 J. Kreft, Media a ekonomia uwagi, „Studia Medioznawcze” 2009, No. 3, p. 145.

7 A. Leszczyński, Co dalej z demokracja, „Gazeta Wyborcza” 2007, No. 169, p. 12.

8 A. Nalewajk, „Gwiazdy tańczą na lodzie” misją TVP, „Dziennik”, 28.04.2008, http:// wiadomosci.dziennik.pl/wydarzenia/artykuly/74780,gwiazdy-tancza-na-lodzie-misjatvp.html [1210.2010].
} 
seems to lose its sense, as their character is identical with that of private stations.

What attracts attention are often borderline situations, e.g. death. Other attractive topics are crisis and violence. The images of war and misery often dominate the program, as they increase viewership. According to Lucyna $\operatorname{Szot}^{9}$ „scandals pay off”. They attract the viewers attention and intensify the emotional value of the broadcast, due to which they stay longer in the viewers' memory. The fact that such images are shown repeatedly on different stations is also important.

The mass media promote controversial topics and tend to exert pressure on the authorities and manipulate public opinion. This can be exemplified with the case of avian flu in the beginning of 2006 or the purchase of the vaccines against $\mathrm{A} / \mathrm{H} 1 \mathrm{~N} 1$ at the end of 2009. The views of Poles on these subjects were constructed by the media. The broadcasts caused panic and fear, and in that way they shaped the laymen's opinions on these complicated matters. Motivated by the controversial nature of the subject or by lobbing, e.g. of pharmaceutical concerns interested in a proper shape of medial discourse, tried in fact to influence the government to make particular decisions.

The focus of television on entertainment and sensation is reflected in a high viewership of the programs which have little in common with the promotion of high culture. This can be illustrated with the list of the most popular programs in one week November 2010 presented in Table 2. Although it needs to be admitted that there are as many as two programs from TVP1 in the first five, the two highest positions are occupied by a soap opera and a quiz. A program broadcast by a commercial station was listed in seventh place. However, it is worth noticing that there are only minor discrepancies between the programs visible in positions from two to ten.

\footnotetext{
9 L. Szot, „News” a odpowiedzialność dziennikarza za słowo, [in:] Wojna w mediach, eds. W. Piątkowska-Stępniak, B. Nierenberg, Opole 2007, p. 54.
} 
Table 2. Programs of the highest viewership. Data from November 8, 2010 and November 14, 2010

\begin{tabular}{|c|l|c|c|c|c|c|}
\hline & Title & Station & Date & Start & Amrx1000 & Amr $\%$ \\
\hline 1 & M jak Miłość (soap opera) & TVP2 & 20101108 & $20: 47: 41$ & 8008 & $22.27 \%$ \\
\hline 2 & Jaka to melodia? (quiz) & TVP1 & 20101114 & $18: 25: 30$ & 5376 & $14.95 \%$ \\
\hline 3 & Sport (sport program) & TVP1 & 20101114 & $19: 55: 11$ & 5285 & $14.70 \%$ \\
\hline 4 & Teleexpress (news bulletin) & TVP1 & 20101114 & $17: 00: 04$ & 5260 & $14.63 \%$ \\
\hline 5 & Barwy życia - kulisy (series) & TVP2 & 20101109 & $20: 42: 08$ & 5186 & $14.42 \%$ \\
\hline 6 & Barwy szczęścia (series) & TVP2 & 20101108 & $20: 11: 26$ & 5158 & $14.35 \%$ \\
\hline 7 & Mam talent! (show) & TVN & 20101113 & $19: 59: 39$ & 5131 & $14.27 \%$ \\
\hline 8 & Wiadomości (news bulletin) & TVP1 & 20101108 & $19: 30: 05$ & 5004 & $13.92 \%$ \\
\hline 9 & Taniec z gwiazdami (show) & TVN & 20101114 & $20: 01: 29$ & 4970 & $13.82 \%$ \\
\hline 10 & Fakty (news bulletin) & TVN & 20101109 & $19: 00: 04$ & 4939 & $13.74 \%$ \\
\hline
\end{tabular}

Source: Nielsen Audience Measurement, http://www.agbnielsen.pl/2010-11-14,1524.html [DOE November 18, 2010].

As a result, there is advertisers' demand for broadcasting their ads in this particular medium. The comparison presented in Table 3. shows that the highest viewership in the week analyzed concerned public television. The results of the two channels of public television and two major commercial stations depict that they share the viewership.

However, the advertisers' expenses, presented in Table 4. reflect a different tendency. It was commercial stations that got the highest income from advertisement. This might be the consequence of a greater number of ads broadcast. The second reason might consist of a stronger interest of different trades in the channels in question, as they have lower confidence in the politicized public media. Last but not least, the rates in public television are slightly higher ${ }^{10}$.

\footnotetext{
10 Cennik reklam TVN. 2010, http://www.tvn.pl/grupatvn/advertising [12.11.2010]; Cennik reklam TV. 2010, http://brtvp.pl/niezbednik/cennik/ [12.11.2010].
} 
Table 3. Weekly participation of stations in viewership. Data from November 8, 2010 and November 14, 2010

\begin{tabular}{|c|c|c|}
\hline & Station & SHR\% \\
\hline 1 & TVP1 & $18.10 \%$ \\
\hline 2 & TVN & $16.09 \%$ \\
\hline 3 & TVP2 & $15.74 \%$ \\
\hline 4 & Polsat & $14.77 \%$ \\
\hline
\end{tabular}

SHR \% - the participation in television audience; specifies how many of the people who watched television at a certain moment were the audience of a given station; it answers the question of what was the participation in television audience?

Source: [Nielsen Audience Measurement 2010].

Table 4. Weekly expenses on advertisement in particular stations. Data from November 8, 2010 and November 14, 2010

\begin{tabular}{|c|l|c|c|}
\hline & Station & Expenses & Percentage \\
\hline 1 & TVN & $85102180.00 \mathrm{zł}$ & $20.18 \%$ \\
\hline 2 & Polsat & $60328922.50 \mathrm{zł}$ & $14.31 \%$ \\
\hline 3 & TVP1 & $52293980.00 \mathrm{zł}$ & $12.40 \%$ \\
\hline 4 & TVP2 & $40394430.00 \mathrm{zł}$ & $9.58 \%$ \\
\hline
\end{tabular}

Source: [Nielsen Audience Measurement 2010].

The data presented above concern the research of a single week. The analysis of particular months, however, gives similar results. Public television competes with the private media for viewers and often wins this competition.

It is worth noticing that the public media use their domination in the advertising market. The income from license fees, though insignificant, can constitute at least a part of the funds that can be spent on the production and broadcast of programs. In consequence, public television may offer lower prices for advertisers, as it takes advantage of the license fee. This was criticized in 2004, when the Agora concern (the publisher of the most popular Polish journals, e.g. Gazeta Wyborcza), TVN and Polsat 
fought for a ban on the monopolistic practices of TVP ${ }^{11}$, in the case of the aforesaid program "Stars Dancing on Ice" and at the beginning of the world crisis, when entrepreneurs trying to reduce their expenses on advertisement. This mainly affected the commercial media, for which advertisement constitutes the main source of income.

Other evidence for the commercialization of the media is the comparison of the number of advertisements broadcast in the space of years. In 1994 TVP broadcast 321 hours of ads, which constituted $5.3 \%$ of the whole program. In 2005 this number increased to 760 hours and 10\% of the total program (10 minute of ads per hour of program). Such an attitude resulted in the protest of private broadcasters, who without success intervened in the National Broadcasting Council ${ }^{12}$. According to Karol Jakubowicz $^{13}$ the low cost of license fees in the financing of TVP, instead of preparing it for better competition, became a trap of dependencies on advertisement. What is more, this situation lead to marginalization of regional branches of TVP which deprived of wider access to the income from advertisement fall into financial problems. As Jakubowicz puts it ${ }^{14}$, the fact that TVP takes income from ads deprives this public broadcaster of its sovereignty.

Seemingly, public television as a medium attractive for the advertiser could not function without the income license fee. Radio, on the other hand, is not as persuasive and its income from ads is much lower, which is reflected in its financial problems. In 2005 the income of both private and public television amounted for $6346000000 \mathrm{zł} \mathrm{(54 \% ),} \mathrm{while} \mathrm{that} \mathrm{of}$ radio, once again both private and public, for $1197000000 \mathrm{zł}(10 \%)^{15}$. This results from the fact that radio is less attractive for advertisers and

11 Pach, Telewizja rabatowa, "Gazeta Wyborcza” 2004, No. 10, p. 21.

12 The National Broadcasting Council is the only regulator of the Polish media market.

13 K. Jakubowicz, Media publiczne: początek końca czy nowy początek, Warszawa 2007, pp. 238-239.

14 K. Jakubowicz, Misja czy emisja, "Rzeczpospolita" 2004, No. 3355, p. X1.

15 Radio i telewizja w Polsce: Raport o stanie rynku. Materiał źródłowy do dokumentu: „Raport otwarcia: rynek radiowo-telewizyjny w Polsce”, Warszawa 2006, p. 33. 
that its level of commercialization, if compared to television, is much lower.

Therefore, it should not be surprising that the directors of particular stations aim at increasing the limit of time that can be devoted to adverts and sponsoring. This situation, however, has its consequences. Advertisers invest in the time with the biggest audience and what the audience particularly enjoys are commercial programs. Therefore, journalistic or educational programs are not produced as eagerly as entertaining ones.

According to Jakubowicz ${ }^{16}$, ,it can be said about the public media that they ought to be public in their program and commercial in their management in order to achieve speed and effectiveness of action indispensable in the fast-changing competitive market and in the need of being more economical in spending their funds. The case seems different, at least in the case of TVP - what is commercial is the program, the management, on the other hand, is public, that is badly-organized and ineffective." For this reason, any accusations concerning the use of dishonest competition by the public media may turn out to be legitimate. This does not mean that TVP1 or TVP2 should be deprived of the possibility to broadcast entertaining programs, but to stop using the term "public" when it no longer expresses the character of a given station.

Nonetheless, any attempts of reorganization are limited to political discussions or arguments focusing on one specific question, namely who is going to have the influence on public media? Key aspects, such as digitalization or the increase in the effectiveness of collecting license fee are rarely the subject of debate. Such debates usually take place between media scholars and journalists who do not possess legislative initiative and are forced to ask politicians for help. Politicians, in turn, are not interested in certain matters essential for the proper functioning of not only the public media, but the media market as a whole.

Therefore, the fact that Poland is facing a media crisis now should not be surprising. Karol Jakubowicz ${ }^{17}$ enumerates several reasons for of this. The first is the crisis of the government's twofold policy directed towards

16 K. Jakubowicz, Media publiczne: początek końca czy nowy początek..., p. 146.

17 Ibidem, pp. 248-257. 
the media, which consists in the fact that the state specifies the tasks of the public media but fails to create proper conditions for the media to complete these tasks. The second is the identity crisis resulting from the necessity to fulfill the mission and simultaneously search for income from advertisement, which leads to the commercialization of the public media. The third type is the crisis of the validity of existence, which is the consequence of the lack of social acceptance of the public media. The fourth is the management crisis, which includes the manner of appointing the organs of companies and negotiating a system of management in the media managing bodies. The fifth is the financing crisis connected to the fact that the license fee constitutes a small part of the total budget of the media. The sixth is the crisis of technological retardation. All the problems presented above contribute to the commercialization of the Polish public media.

This tendency has been present in the media all over the world for several decades. Walter Lippmann ${ }^{18}$ wrote about it in the 1920's. In Poland, however, such phenomenon is relatively new. For this reason it is worth paying more attention to it, the more so because the media differ from ordinary enterprises producing clothes or furniture. They shape people's opinion, decide on their perception of the world and play the role of school or churches in the education of young people. Any pathologies observable in the media are in a way transferred to society.

The public media of today in numerous countries are accused of bad management, overcommercialization and brutalization of language. This results from certain world-wide tendencies: the concentration of capital and commercialization. Several decades ago editorial offices were dependent on the state and politicians. Nowadays this dependence is becoming less and less important and a new form of organization is being introduced. According to Ryszard Kapuściński ${ }^{19}$, „the old idealistic seekers of truth, wielding power in the world of the media, were replaced with businessmen who frequently lack any knowledge of journalism (...). The one in power is the one that is in control of the television studio or the media in general."

18 W. Lippmann, Public opinion, New York 1965, pp. 3-20.

19 R. Kapuściński, Lapidarium IV, Warszawa 2000, pp. 89-90. 
Consequently, the commercialization of Polish media seems unavoidable, regardless of political or social will. To a large extent, commercialization takes place due to a lack of any actions performed by the government. The case of France and the changes concerning the financing of the public media recently introduced in this country show that the state is able to stop the process of commercialization only when such is political will. 